\title{
Conflict in the South China Sea and Exports to China Within the Asean-China Free Trade Agreement Framework
}

\author{
Muhammad Imam*, Maddaremmeng A. Panennungi
}

Faculty of Economics and Business, Universitas Indonesia

*Corresponding author. Email: muh.imamfauzi@gmail.com

\begin{abstract}
The ASEAN-China Free Trade Agreement (ACFTA), a regional trade agreement signed in 2004, established free trade for goods among participating countries. The ACFTA removed tariffs on goods beginning in 2010 for trade between ASEAN and China. However, trade cooperation between ASEAN and China has been problematic, involving tensions and disputes between several ASEAN countries and China over territorial claims in the South China Sea. This study aims to analyze the relationship between territorial conflicts in the South China Sea and the export of goods from ASEAN countries to China within the ACFTA framework. This study uses panel data for ten ASEAN countries for the period 2004-2015, and differences-in-differences and regression tests as the methods of analysis. The result of the differences-in-differences method finds that removing the ACFTA tariff in 2010 decreased exports from the countries involved in conflicts. The estimation result finds that the rising intensity of conflicts in the South China Sea significantly reduced exports from ASEAN countries involved in those conflicts to China.
\end{abstract}

Keywords: ACFTA, Export, Territorial Conflict

\section{INTRODUCTION}

The ASEAN-China Free Trade Agreement (ACFTA) is a Free Trade Agreement that involves an agreement between the Association of Southeast Asian Nations (ASEAN) member countries and China to create a free trade area by removing trade tariffs. The agreement began with the signing of the Agreement on Trade in Goods of the Framework Agreement on Comprehensive Economic Cooperation between the ASEAN and the People's Republic of China. This agreement includes the removal of tariffs on goods on Normal and Sensitive Track, except for the Early Harvest Program, which aimed for zero tariffs by 2010.

Table 1. Trade in Good Agreement Tariff Rates

\begin{tabular}{|c|c|c|c|c|}
\hline \multirow{2}{*}{$\begin{array}{c}\text { X= Applied MFN } \\
\text { Tariff Rate }\end{array}$} & 2005 & 2007 & 2009 & 2010 \\
\cline { 2 - 5 } & 20 & 12 & 5 & 0 \\
\hline $\mathrm{X}>20 \%$ & 15 & 8 & 5 & 0 \\
\hline $15 \%<\mathrm{X}<20 \%$ & 10 & 8 & 5 & 0 \\
\hline $10 \%<\mathrm{X}<15 \%$ & 5 & 5 & 0 & 0 \\
\hline $5 \%<\mathrm{X}<10 \%$ & 0 & 0 & 0 & 0 \\
\hline $\mathrm{X}<5 \%$ & & & \multicolumn{4}{|c|}{ ACFTA Preferential Tariff Rate } \\
\hline
\end{tabular}

Source: ASEAN Secretariat (2018) 
Before the ACFTA was established, the United States was the largest trading partner for the majority of ASEAN countries, especially Indonesia. But after the ACFTA, China became the biggest trade partner for the majority of ASEAN countries, including Indonesia.

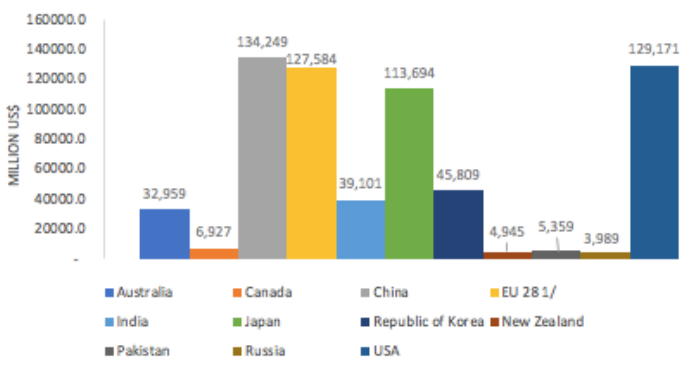

Figure 1 The Value of Exports of ASEAN by Country Partners in 2015

The value of ASEAN and Chinese exports increased almost every year since the ACFTA was signed. Figure II shows that the value of exports between the ASEAN and China from 2005-2014. The decrease in the value of exports in 2009 was during the global financial crises. (IMF, 2016).

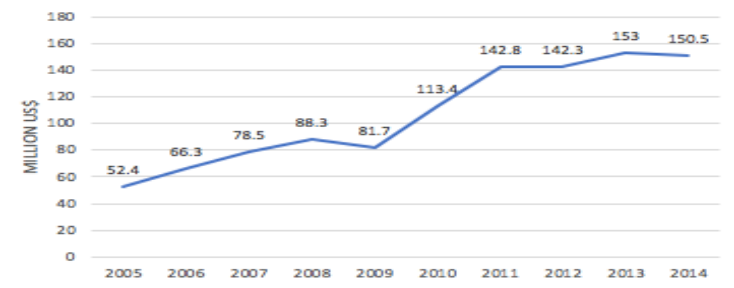

Figure 2 ASEAN's Export Value to China in 20052014

For the ASEAN countries, China became an important trading partner as the destination country for exports. Figure III shows the value of exports to China by ASEAN countries in 2005 and 2015. The value of exports from ASEAN countries to China increased significantly between 2005 and 2015, especially for Indonesia, Malaysia, Thailand, Singapore, and Vietnam. In general, trade between ASEAN countries and China increased, indicating the growing importance of the ACFTA for the regional economy.

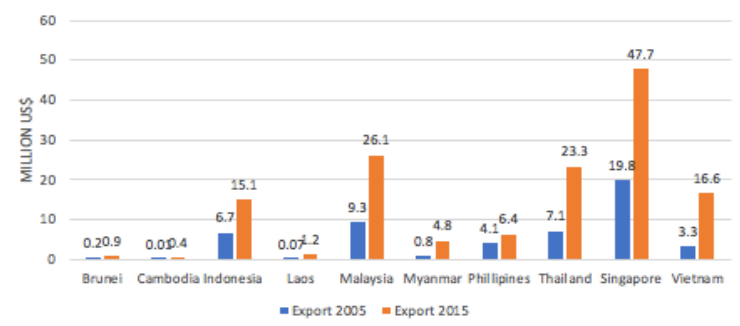

Figure 3 The Export Value of Each of the ASEAN Countries to China in 2005 and 2015
Although the ACFTA has increased the value of trade, relationships between the member countries face a variety of obstacles. One of the obstacles is the conflicting interests of the member states (Zhao, 2013). Differing interests among countries in the region have the potential to cause conflict and instability both regionally and globally. Conflicting interests among member countries may occur as a result of economic, political, or social interests and if not addressed, can result in a military conflict among countries. There is also a fear of conflict arising as a result of different views with respect to claims of ownership and control of the South China Sea and its resources, involving many ASEAN countries and China (Yujuico, 2010; Simmons, 2005). The following map shows the countries with territorial claims in the South China Sea.

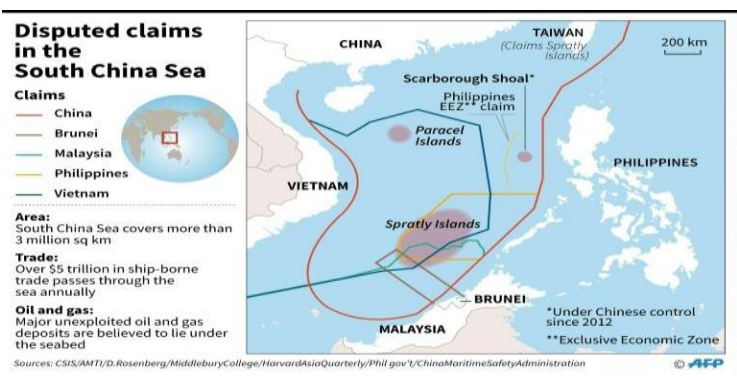

Figure 4 Map of Territorial Claims in the South China Sea

It is interesting to see the economic relationships and the dynamics of the politics involving the South China Sea. According to many experts, conflict between countries will reduce dependence and decrease economic integration (Keohane, 1998). This is because economic integration and dependence increase incentives to cooperate and reduce the odds of conflicts. Many economists also believe that countries in an integrated economy tend to be cooperative and wish to prevent conflict.

However, events that have taken place in the South China Sea do not support these predictions. Increased economic integration and interdependence between countries have not led to cooperation and conflict resolution in the South China Sea. Territorial claims in the South China Sea between the ASEAN countries and China have led to several incidents in the South China Sea in recent years, as shown in Figure IV. The number of conflicts has increased as the value of trade between China and ASEAN countries has increased. 


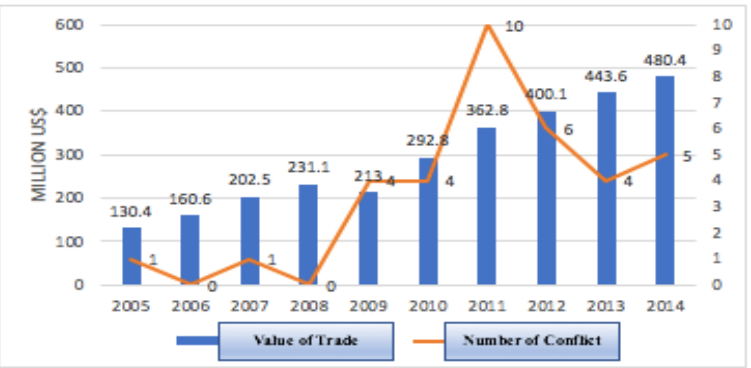

Figure 5 Conflict in the South China Sea in 20052014

The likelihood of conflicts in the South China Sea can be seen from a country's military budget. A growing budget for military spending indicates a country's political direction. The following figures show China's military spending has grown far more rapidly than military spending by other countries in the region. According to Mearsheimer (2001), a country with a strong military and a strong economy would be a dangerous competitor to surrounding countries. China's military capabilities have increased significantly while the frequency of open conflicts in the South China Sea with countries involved in ASEAN have also increased.

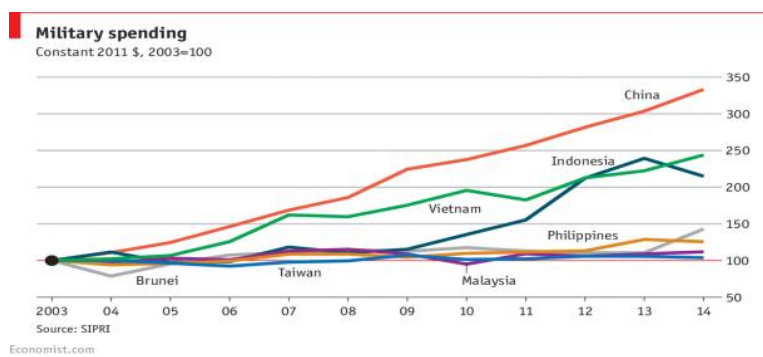

Figure 6 Military Budgets of Countries in the South China Sea

There are two general perspectives regarding conflict and trade relations between countries. One side argues that conflict reduces the trade, while the other side argues the opposite, that conflict does not reduce trade. Conflict should reduce trade, according to the first point of view, because of the disruption in production, distribution of goods and services, and purchasing power of consumers; the opposing view says that conflict does not reduce trade when economic and trade dependency between countries are strong (Keen, 2002).

The relationship between trade and territorial conflicts between countries has been scrutinized by many academics, and by political and economic security experts, especially in terms of differences between realist and liberal perspectives. The realist determines that conflict's influence on trade is negative due to increasing economic costs to trade between the parties. On the other hand, the liberal view states that conflict does not reduce trade; on the contrary, trade will improve the economies of both countries and will reduce the prevalence of conflict between trading partners because of an expectation that costs would increase and economic losses would occur.

In economics, there are few studies of relationship conflicts involving territorial trade. Polachek (1980) was the first to develop a model of relationship conflict and trade. According to the model, conflicts cause economic losses because trade becomes more difficult when a conflict occurs. Both parties in the trading relationship do not want to engage in an ongoing conflict. Empirical studies of Polachek's argument have not been done (Polachek and Seiglie, 2007).

Polachek's argument should be researched and tested in the context of the conflict in the South China Sea, where the countries are involved in economic integration. Territorial disputes between China and four of the ASEAN countries (Vietnam, Philippines, Malaysia, and Brunei) are complex and the conflict involves many parties. Researchers may be interested in investigating whether the conflict between China and the ASEAN countries will reduce the value of trade, particularly with respect to ASEAN countries' exports to China. Based on the description and the results of previous research, we formulate the following research question:

"How does territorial conflict in the South China Sea affect ASEAN countries' exports to China within the implementation of the ACFTA?"

This research was conducted to analyze the impact of territorial conflicts in the South China Sea in the period 2004-2015. The ACFTA agreement reducing trade tariffs was signed in 2004, and tariffs were elimination for the majority of goods in 2010 .

This study uses panel data (Gujarati, 2006), obtained from publications of the Indonesia Central Bureau for Statistics (BPS), World Bank, WTO, UN Comtrade, Ministry of Commerce, and other academic journals for the period January 2004December 2015. The variables in the model included the value of exports (EKSP) as the dependent variable and the interaction between implementation of ACFTA and treatment group variable (ACFTAxCONF), the intensity of the conflict (No_Military, Threat_Force), Display_Force and Use_Force), a dummy implementation of ACFTA (ACFTA), a dummy of treatment group countries (CONF), real gross domestic product (PDBCHN and PDBMEMBER) and trade costs (TC) as the independent variables. 


\section{LITERATURE REVIEW}

\subsection{Conflict Theory on Trade}

The relationship between conflict and bilateral trade is one of the important topics in international political economy-related research. Economic entities have deep concerns about the impact of the increasing intensity of conflict on trade. There are reasons conflict can affect the economic relations between two countries.

In this section, we discuss in greater detail the two schools of thought, i.e., realist and liberal thinkers, concerning the relationship between conflict and trade.

\subsubsection{Realist Perspective (politics first)}

According to the realist perspective, the political and security factors that cause conflict will have a negative impact on the economic relations of the countries involved. A country that prioritizes the sustainability of its economy will act carefully and avoid economic actions toward other countries that will contribute to a poor political relationship. The reason is that poor relations with other countries can weaken or strengthen its own economy (Kirshner, 1999). Gowa and Mansfield (1993) state that political and security relations will influence patterns of international trade because trade based on cooperation between countries. A shift in the level of political cooperation and stability of the countries can be the deciding factor of bilateral economic relations (Mastanduno, 1998).

The most common argument used by the realist thinkers is "trading follows the flag" which means that economic actors within a given country will observe the bilateral political relations with another country and will consider the likelihood of conflict between them before trading with each other. Pollins (1989) determined that a country would trade with other countries with whom it has good political relationships to prevent risks and reduce potential disruption to the economy. Consumers in a country will support and maintain economic solidarity with other countries that are regarded as associates or partners, and will avoid trade with countries regarded as rivals or opponents. As a result, bilateral trade will be correlated with shifts in political relationships, even in the absence of government policies with other countries. Pollins notes that it is not only open conflict that has this affect, but also that the orientation of a given country's foreign policy toward other countries impacts the level of bilateral trade.
Furthermore, countries that have similar policies with respect to global issues will be more likely to trade with each other (William and Moon, 1993). Equality in the political systems of the two countries will encourage trade flow because both economic actors receive relevant information about business trends, preferences, and the limitations of government regulation (Bliss and Russett, 1998).

The above explanation can be summarized into the first hypothesis, which is that increasing political tension and conflict between two countries leads to reduced trade flows and encourages a country to seek trade and investment opportunities with other countries.

\subsubsection{Liberal Perspective (economy first)}

In contrast to realist thinkers who believe that conflict and tension reduce the level of trade between two countries, liberal thinkers argue that conflict will not affect trade. This group points out that the negative influence of conflict on bilateral trade is not significant. Maoz (2009) conducted a series of experiments using economic data and found strong evidence that conflict did not significantly affect bilateral trade.

There are two factors supporting the view that conflict does not reduce trade (Barbieri, 2002; Mansfield and Pollins, 2003). First, the impact of the larger economic interests of economic actors (Polachek, 1980). Economic actors who benefit from trade will lobby the government to avoid further conflict with partner countries (Kastner, 2007). Pressure from businesses is expected to support the country's positive relationship with partner countries and prevent conflict. Second, both countries are economic dependent on each other. Liberal thinkers argue that conflict does not reduce economic transactions between countries due to the need for an ongoing exchange of goods and services with the each other; therefore, conflicts would not reduce economic and trade cooperation. Gartzke et al (2001) mention that when both countries depend on the flow of trade and investment, political interests are overpowered by economic interest. In other words, economic interests are superior to political interests.

This reasoning counters the assumption that political conflicts will harm economic relations. Concerns about the decreased trade due to a worsening political relationship between countries create an incentive to support good political relationships. The danger a political conflict poses to economic cooperation is avoided by signaling to both countries the need to increase economic relations. The liberalists argue that military conflict will have little impact on trade because the economic actors 
have anticipated and adjusted their economic activities before the political tension rises (Morrow, 1999).

Based on this explanation, we come to the second hypothesis: increasing conflict and political tension between both countries do not have a negative impact on economic relations and trade between two countries.

\subsection{Previous Studies}

Previous studies have been conducted regarding the influence of conflict on trade. Studies that support the argument that conflict reduces economic activity and trade include Gowa and Mansfield (1993); Martin, et al (2008); Li and Vaschilko (2010); and Oetzel and Getz (2012). Gowa and Mansfield (1993) studied the impact of cooperation or alliances on trade flow by estimating a game theory model with a gravity equation. They include dummy variables for bilateral and multilateral alliances and wars between countries. They found that war between countries has a negative impact on trade. Martin, et al (1998) support the findings in Gowa and Mansfield. They examined the use of the gravity equation to predict the negative impact of war on trade. They found the negative impact lasts a long time after the war has ended.

Other studies followed different approaches. $\mathrm{Li}$ and Vashchilko (2010) did not see an impact of conflict on the total economy of the countries. They analyzed business conditions that were affected due to conflict in 58 countries from 1980 to 2000 using the gravity model and panel data regression. According to their results, armed conflict tends to harm a country's infrastructure, leading to a disruption in production and distribution for that country. The impacts include delayed investment from outside the country, so the government may have to provide subsidies to support the stability of the country's businesses. Another negative impact of conflict focuses on the analysis of managerial issues and challenges for companies in the area of conflict. Research by Getz and Oetzel (2012) also supports the statement of Li and Vashchilko. Getz and Oetzel use a regression analysis on panel data of 470 foreign companies in 80 countries and found that various types of security-related challenges and military aggression can destroy businesses immediately. Their research contributes to the investigation of current global trade disruptions produced by political conflict and other types of security threats, including terrorism and tense diplomatic relations.

In contrast, some researchers have found that conflict does not reduce bilateral trade (Morrow, et al, 1998; Barbiery and Levy, 1999; Anderson and
Carter, 2003; Glick and Taylor, 2005; and Bayene, 2015). Morrow, et al (1998) analyzed the determinants of international trade and include variables such as war between the two countries as well as the variable of democracy and political alliance. They found that alliances were not significant in trade relations between two countries. Morrow concluded that conflict did not have a significant influence on trade because business actors anticipated the potential conflict in the business activity, a conclusion that differs from $\mathrm{Li}$ and Vashchilko, and from Oetzel and Getz. Related research by Beyene (2015) studied the influence of conflict on the economic cooperation of countries in Africa. Bayene found that conflict does not affect trade, and that progress in trade reduced the likelihood of conflicts.

Other researchers look specifically at the impact of military conflicts on trade. Barbieri and Levy (1999) argue that conflict does not automatically reduce trade. Barbieri and Levy examined the bilateral economic relations between the seven pairs of countries that experienced conflict. They found that conflict does not lead to disruption in trade. However, the limitation of this research is that it is difficult to generalize based on the limited number of samples. For that reason, Anderson and Carter (2003) and Glick and Taylor (2005) examined with a larger number of samples. They found that conflict did not have a negative impact on trade.

Research related to the impact of territorial conflict on bilateral trade within a regional economic integration, in this case between China and ASEAN, is rare. Moreover, the conflict between China and the ASEAN countries in the South China Sea has existed for a long time. Therefore, we focus on the impact of territorial conflict on ASEAN countries' exports to China amid territorial conflicts.

\section{RESEARCH METHOD}

This study focuses on the ASEAN member countries (Indonesia, Malaysia, Singapore, Brunei, Philippines, Thailand, Myanmar, Vietnam, Cambodia, and Laos) within the framework of ACFTA.

Although many studies estimate the impact of ACFTA, very few of them assess the impact of conflict among the ACFTA countries. Moreover, the agreement to eliminate trade barriers in 2010 meant that previous studies did not have relevant data.

This study uses two methods to analyze the impact of conflict within ACFTA on toward exports from ASEAN countries to China. These methods are the proportionate average calculation of the difference-in-difference (DiD), and an estimation 
method using the difference-in-difference and intensity of the conflict as the primary variables.

The first approach uses the DiD method. DiD is a policy evaluation approach that entails two periods of time, i.e., before and after treatment (treatment) and observations for two groups, the treatment group and the control group (Abadie, 2005). In this research, the treatment is the elimination of tariffs in 2010 via the ACFTA. The treatment group consists of ASEAN countries that have a territorial conflict with China in the South China Sea (Vietnam, Philippines, Malaysia, and Brunei) and a control group of ASEAN countries that do not have territorial conflicts with China in the South China Sea (Indonesia, Singapore, Thailand, Cambodia, Laos, and Myanmar). The framework of the DiD method is shown in the following equation:

$$
\text { Impact }=(\mathrm{T} 2-\mathrm{T} 1)-(\mathrm{C} 2-\mathrm{C} 1)
$$

Source: Lipsey (2004)

Where T1 and T2 are export values for ASEAN countries in conflict with China before and after the tariff elimination of ACFTA, while $\mathrm{C} 1$ and $\mathrm{C} 2$ are export values for the ASEAN countries that are not in conflict with China in the same period. If the impact is different from 0 , then the implementation of ACFTA has an impact on ASEAN countries involved in conflicts with China in the South China Sea.

The benefit of the DiD method is that data can be grouped to create a condition for an experiment between a treatment group and a control group. The use of a control group can help to analyze changes in the pattern of trade of ASEAN countries in ACFTA. For example, the control group of countries that are not in conflict with China is used to test whether the
ACFTA causes an increase in the value of exports of these countries to China compared to the ASEAN countries in conflict.

The initial stage of data analysis using the DiD test seeks to determine whether there is a difference between the pre-and post-treatment conditions of the treatment group and control group, based on the indicators that will be observed. In addition, a regression analysis is necessary to consider other factors that may affect the value of exports from ASEAN countries to China.

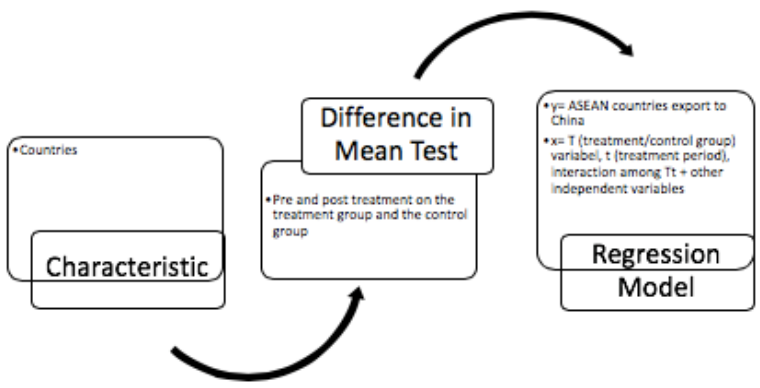

Figure 7 Analysis of Pathway of DiD Method

First, we select indicators for countries that will be analyzed. Some of these indicators are tested for a difference in means before and after treatment for both the treatment group and the control group.

Next, the impact of a program can be measured by comparing the treatment group indicator to the control group indicator after the program/treatment. Given data collected before and after treatment, the DiD is used to calculate the impact of the treatment, in this case, the elimination of tariffs through ACFTA. The result can be interpreted as the impact of the treatment.

Table 2. Calculation of the Impact of ACFTA with DiD

\begin{tabular}{|l|c|c|l|}
\hline & Treatment Group & Control Group & $\begin{array}{l}\text { Difference between } \\
\text { Groups }\end{array}$ \\
\hline Before ACFTA & T1 & C1 & (T1-C1) \\
\hline After ACFTA & T2 & C2 & (T2-C2) \\
\hline Difference over time & (T1-T2) & (C1-C2) & \\
\hline
\end{tabular}

Source: Lipsey (2004)

The following method estimates variables that affect the indicators in the model. Regressions are used as the main tool in the estimation model. We use the gravity model of trade which has been commonly used to test the flow of trade between two countries since the 1960s (Linneman, 1966; Tinbergen, 1962). We are interested in determining the impact of territorial conflict on trade relations between countries. Territorial conflicts in the South
China Sea involve a number of ASEAN countries and China. In this study, we use two conflict variables based on empirical studies of other countries to address the impact of conflict on trade. The first variable is the interaction effect of the implementation of ACFTA and conflict (ACFTAxCONF). The second variable is an index of the intensity of the conflict between individual 
ASEAN countries and China used in research on conflict and trade (Simmons, 2005).

Variable of interactions between groups of countries involved in conflict and the implementation of ACFTA is a variable in the form of qualitative data. In order to be used in the regression as a dummy variable, the data is converted into a binary data with value 0 or 1 . Countries involved in ACFTA that have had territorial conflicts with China since 2010 are assigned a value of 1 ; otherwise, a value of 0 is given. Our assumption is that the group of ASEAN countries with conflicts in the South China Sea will have reduced exports to China after ACFTA 2010 , i.e., the relationship is negative. The variable of intensity of the conflict will see relationship of two countries by the level of intensity of conflicts. The intensity of conflict is measured by a number ranging from 1 to 5 , where the higher the number the worse the conflicts between the two countries. The assumption is the higher the number (the worse the conflict for the two countries), the more the value of exports from ASEAN countries to China will be reduced. The lowest level of the conflict is given a value of 1, for No Military Action, while the highest degree is given a value of 5, i.e., an incidence of war. In the model, the intensity of the conflict is in the form of dummy variables from 1 to 4, i.e., No Military Action (No_Military), Threat to Use Force (Threat_Force), Display Ability to Use Force (Display_Force) and the Use of Force (Use_Force).
The highest conflict intensity (5), i.e., war, is not used since war did not occur during this period.

To understand the influence of territorial conflicts in the South China Sea on trade between ASEAN countries and China, we include the variable interactions between conflict and the implementation of ACFTA (ACFTAxCONF) and intensity of conflict between ASEAN countries and China. Model estimates are obtained using random effects models.

1) The first model analyzes the impact on ASEAN exports of for countries involved in conflicts with China in the South China Sea and the implementation of ACFTA.

In $(\mathrm{EKSP})$ it $=\beta 0+\beta 1(\mathrm{ACFTAxCONF})$ it $+\beta 2$ $($ ACFTA $) t+\beta 3($ CONF) it $+\beta 4$ in $(\mathrm{PDBCHN}) \mathrm{t}+$ $\beta 5$ In (PDBMEMBER) it $+\beta 6$ in (TC) it $+\varepsilon$ it

2) The second model analyzes the impact of the intensity of conflict on ASEAN exports to China.

In (EKSP) it $=\beta 0+\beta 1$ (No_Military) it $+\beta 2$ (Threat_Force) it $+\beta 3$ (Display_Force) it $+\beta 4$ (Use_Force) it $+\beta 5$ (ACFTA) $t+\beta 6$ in (PDBCHN) $t$ $+\beta 7$ in (PDBMEMBER) it

$+\beta 8$ in (TC) it $+\varepsilon$ it

The data are obtained from the secondary sources noted earlier, via the internet. The variables in this study together with a data source used are seen in the following table:

Table 3. Variables, Description and Data Sources

\begin{tabular}{|c|c|c|}
\hline Variable & Description & The Data source \\
\hline In (EKSP) it & $\begin{array}{l}\text { The log of nominal value of export of ASEAN } \\
\text { countries to China (in million US \$) }\end{array}$ & COMTRADE \\
\hline (ACFTAxCONF) it & $\begin{array}{l}\text { The interaction between treatment group } \\
\text { and dummy group }\end{array}$ & Data Binary \\
\hline$($ ACFTA) $t$ & $\begin{array}{l}\text { The implementation of ACFTA treatment } \\
\text { Before the ACFTA 2010: } 0 \\
\text { After the ACFTA 2010: } 1\end{array}$ & Data Binary \\
\hline (CONF) it & $\begin{array}{l}\text { Territorial conflicts in the South China Sea } \\
\text { Countries involved in conflict: } 1 \\
\text { Countries not involved in conflict: } 0\end{array}$ & Data Binary \\
\hline $\begin{array}{l}\text { 1. (No_Military) it } \\
\text { 2. (Threat_Force) it } \\
\text { 3. (Display_Force) it } \\
\text { 4. (Use_Force) it }\end{array}$ & $\begin{array}{l}\text { The Index of the intensity of conflict } \\
\text { 1: No militarized action } \\
\text { 2: Threat to use force } \\
\text { 3: Display use of force } \\
\text { 4: Use of force } \\
\text { 5: War }\end{array}$ & $\begin{array}{c}\text { MID COW Project } \\
\text { Pensylvania State } \\
\text { University, UCDP (Uppsala } \\
\text { Conflict Data Program) }\end{array}$ \\
\hline In (PDBCHN) t & Real GDP of China (in million US \$) & World Bank \\
\hline In (PDBMEMBER) it & real GDP of ASEAN countries (in million US \$) & World Bank \\
\hline In (TC) it & $\begin{array}{l}\text { The cost of the trade of ASEAN countries to } \\
\text { China (in index) }\end{array}$ & UNESCAP \\
\hline
\end{tabular}


Notes: Where $\ln$ denotes variables in natural logs, $i$ indicates exporter and $t$ indicates time period.

\section{DISCUSSION}

\subsection{Difference-in-difference Method}

The DiD is a method of measuring the impact of a program or treatment by comparing the results or value of the indicator between the treatment and control groups over the treatment period. This study looks at the value of exports between the countries in conflict and the countries not in conflict in the South China Sea, before and after the ACFTA tariff elimination in 2010 is implemented. Table 4 shows the results of the DiD calculation:

Table 4. Average Changes Before and After ACFTA by DiD Method

\begin{tabular}{|c|c|c|c|}
\hline & Treatment Group & Control Group & $\begin{array}{c}\text { The difference } \\
\text { between group }\end{array}$ \\
\hline Before Treatment & 5542.718 & 7736.7507 & -2194.0327 \\
\hline After Treatment & 12021.906 & 15518.327 & -3496.421 \\
\hline $\begin{array}{c}\text { The difference } \\
\text { between time }\end{array}$ & 6479.188 & 7781.5763 & \\
\hline
\end{tabular}

Note: The numbers above are the average proportionate changes to categories of exports between

\section{before and after the implementation of ACFTA 2010.}

The table above represents the differences in the change in the value of exports between the treatment and control groups before and after ACFTA eliminated tariffs in 2010. While the treatment group experiences an increase in export values after ACFTA 2010, the value is below the increase in the export value of the control group.

Table 5. Impact of ACFTA on the Value of Exports of ASEAN Countries in Conflict (the Treatment Group) by DiD Method

\begin{tabular}{|c|c|c|c|}
\hline & Treatment & Control & Impact \\
\hline Value of Export & 6479.188 & 7781.577 & $\mathbf{- 1 3 0 2 . 3 8 9}$ \\
\hline
\end{tabular}

Table $\mathrm{V}$ shows the results of the impact analysis. The impact of ACFTA's implementation is -1302.389 , which means that there is a decrease in the export value of 1302.39 for countries involved in South China Sea conflicts with China after ACFTA was implemented in 2010.

\subsection{Regression Method}

Table 6. Estimation Results of Model I

\begin{tabular}{|l|l|l|l|l|}
\hline & Prediction & Sign & Coefficient & prob \\
\hline (ACFTAxCONF) it & - & - & -0.525 & $0.006 * * *$ \\
\hline (ACFTA) t & + & + & 2.816 & 0.353 \\
\hline (CONF) it & - & - & -2.318 & $0.005 * * *$ \\
\hline $\ln ($ PDBCHN) it & + & - & 2.375 & 0.442 \\
\hline In (PDBMEMBER) it & + & + & 1.977 & $0.000^{* * *}$ \\
\hline In (TC) it & - & - & -1.802 & $0.000^{* *}$ \\
\hline
\end{tabular}

Results are estimated using a panel data approach, Random Effect (RE). Based on the estimation, in the aggregate, the impact of the interaction between treatment and treatment group
Regression analysis is used to measure the influence of other variables on exports of ASEAN countries. Model I includes dummy variables for countries in conflict (CONF) and for implementation of ACFTA (ACFTA), and a variable for interactions between the two dummies (DiD). The results of the estimates for model I are shown in Table VI.

(ACFTAxCONF) is significant and negative. Variable of interactions between the implementation of ACFTA and countries in conflict (ACFTAxCONF), variable of dummy variable of 
countries in conflict (CONF), variable of GDP of the ASEAN countries (PDBMEMBER) and variable of TC, are significant with respect to exports from ASEAN countries to China (EKSP), ceteris paribus. The variable of China's real GDP (PDBCHN) and variable for implementation of ACFTA (ACFTA) are statistically insignificant with respect to exports of ASEAN countries to China (EKSP).

The variable of interaction between the treatment group and the ACFTA treatment (ACFTAxCONF) was negative with an estimated coefficient of 0.53 . This shows that exports of ASEAN countries in conflict with China after ACFTA 2010 was implemented decreased by a factor of 0.53 . The variable of the implementation of ACFTA (ACFTA) is not significant. The variable of the conflict in the South China Sea (CONF) is significant and negative with an estimated coefficient of 2.32. This result says that exports of ASEAN countries in conflict with China decreased by a factor of 2.32, a greater decrease compared to ASEAN countries that were not in a conflict with China. The variable of China's real GDP (PDBCHN) negative but not significant, with an estimated coefficient of -2.38 . Next, the variable of ASEAN real GDP (PDBMEMBER) is positive with the estimated coefficient of 1.98. This result indicates that a one percent increase in ASEAN countries real GDP will increase the export of ASEAN countries to China to $1.98 \%$. This is consistent with the hypothesis that higher income increases purchasing power, or, in the context of trade between countries, an increase in real GDP will increase the purchasing power of the countries concerned. Last, the variable of trade cost (TC) is significant and negative with the estimated coefficient of -1.80 . The result suggests that increasing costs of trade between ASEAN countries and China will reduce exports of ASEAN countries to China by a factor of 1.80 .

Model II considers the influence of the intensity of a conflict on the ASEAN countries exports to China.

Table 7. Estimation Results of Model II

\begin{tabular}{|l|c|c|l|l|}
\hline & Prediction & Sign & Coefficient & prob \\
\hline (No_Military) it & - & - & -0.292 & 0.580 \\
\hline (Threat_Force) it & - & - & -0.256 & 0.662 \\
\hline (Display_Force) it & - & - & -0.855 & $0.059^{*}$ \\
\hline (Use_Force)) it & - & - & -0.974 & $0.020^{* *}$ \\
\hline (ACFTA) t & + & + & 2.867 & 0.340 \\
\hline In (PDBCHN) it & + & - & -3.009 & $0.325^{* *}$ \\
\hline In (PDBMEMBER) it & + & + & 2.711 & $0.000^{* * *}$ \\
\hline In (TC) it & - & - & -2.073 & $0.000^{* * *}$ \\
\hline
\end{tabular}

Based on these results, the variable of the Display of Use of Force (Display_Force), the variable of the Use of Force (Use_Force), the variable of the gross domestic product of the ASEAN countries (PDBMEMBER) and the variable of trade cost (TC) are significant in predicting exports from ASEAN countries to China (EKSP), ceteris paribus. The variables of No Military Action (No_Military), Threat of the use of power (Threat_Force), the dummy variable of implementation of ACFTA (ACFTA) and China's real gross domestic product (PDBCHN) are not significant.

For the 4-dummy variable of intensity of conflict, the variable of No Military Action (No_Military) and Threat of Using Force (Threat_Force) are not significant, while the variable for Display of Use of Force (Display_Force) and Use of Force (Use_Force) are significant. All conflict-intensity variables have negative coefficients and the greater the absolute value of the coefficients, the greater the impact of the level of the intensity of the conflict. This means that when the intensity of the conflict increased or conflict worsened between the ASEAN countries to China, exports from ASEAN countries to China were reduced. Other control variables such as the implementation of ACFTA (ACFTA) and China's real GDP were not significant. The variable of ASEAN countries' real GDP (PDBMEMBER) is positive with an estimated coefficient of 2.71. This result means a one percent increase in the Real GDP of ASEAN countries will increase exports of ASEAN countries to China by 2.71 percent. Lastly, the variable of TC is significant and negative with an estimated coefficient of -2.07 . The results suggested that a one percent increase in TCs between ASEAN countries and China will reduce the export of ASEAN countries to China by 2.07 percent.

\section{CONCLUSION}

Our results show that the impact of ACFTA can cause a decrease in export values of ASEAN countries in conflict with China in the South China Sea. Furthermore, the intensity of conflict in the 
South China Sea greatly reduces the exports of ASEAN countries to China.

Based on the above, territorial conflicts in the South China Sea between ASEAN countries and China after the tariff elimination in the ACFTA in 2010 and the intensity of those conflicts greatly reduces ASEAN countries' exports. This conclusion supports the realist hypothesis that conflict will reduce trade because there will be decreased demand for goods due to the disruption in bilateral economic relations, negative business expectations and uncertainties regarding political relations.

Based on this research, the implementation of ACFTA to eliminate tariffs in 2010 increased ASEAN exports to China. However, ACFTA may still face some barriers because of conflicts in the South China Sea. ASEAN countries that wish to increase export and trade are advised to avoid engaging in a conflict with China. For Indonesia, conflicts between other ASEAN countries and China can be opportunities to increase the value of Indonesia's exports to China. This is because ASEAN countries in conflicts with China may look to export to countries other than China, so Indonesia can supply China's demand for exported goods from ASEAN countries.

\section{REFERENCES}

[1] Barbieri, Katherine. "The Liberal Illusion: Does Trade Promote Peace?.” Ann Arbor: Michigan University Press, 2002.

[2] Barbieri, Katherine, and Jack Levy. "Sleeping with the Enemy: The Impact of War on Trade." Journal of Peace Research, 36 (4), 1999, 463-79

[3] Beyene, Hailay. "Does International Trade Reduce Political Disputes?." Foreign Trade Review, 50(2), 2015, 99-117

[4] Bliss, Harry, and Bruce Russett. "Democracy and Trade: Ties of Interest and Community" in Democratic Peace in Europe: Myth or Reality, ed. Gustaaf Geeraerts and Patrick Stouthusyen. Brussels: Free University Press, 1988, 75-90

[5] Dixon, William, and Bruce Moon. "Political Similarity and American Foreign Trade Patterns.” Political Research Quarterly, 46(1), 1993, 5-25

[6] Gartzke, Li, Erik, Quan, and Charles Boehmer. "Investing in the Peace: Economic Interdependence and International Conflict." International Organization, 55(22), 2001, 391438
[7] Glick, Reuven, and Alan Taylor. "Collateral Damage: Trade Disruption and the Economic Impact of War." Working paper no. 11565. National Bureau of Economic Research, Cambridge, MA, 2005.

[8] Gowa, Joanne, and Edward Mansfield. "Power Politics and International Trade." American Political Science Review, 87(2), 1993, 408-420

[9] Gujarati, Damodar. "Basic Econometrics." Jakarta: Eason, 2006.

[10] Keen, David. "Conflict, Trade and Economic Agenda. Support Conflict Transformation Committee." Number of Newsletter 19, 2002.

[11] Kirshner, Jonathan. "The Political Economy of Realism" in Unipolar Politics, ed. Ethan Kapstein and Michael Mastanduno. New York: Columbia University Press, 1999, 88-102

[12] Leszek, B. "The South China Sea: Oils, Maritime Claims, and the US-China Strategic Rivalry." The Washington Quarterly, 35(2), 2012, 139- 156

[13] Li, Quan, and Tatiana Vashchilko. "Diad Military Conflict, Security and Bilateral Alliance." Journal of International Business Sciences, 41(5), 2010, 765-782

[14] Lipsey, M.W et al. "Evaluation: A Systematic Approach." Oaks, CA: Sage Publication Mansfield, Edward, and Brian Pollins, eds. (2003). "Economic Interdependence and International Conflict: New Perspectives on An Enduring Debate." Ann Arbor: University of Michigan Press, 2004.

[15] Martin, Philippe, Thierry Mayer, and Mathias Thoenig. "Making Trade Not War?." Review of Economic Studies, 75(3), 2008, 865-900

[16] Maoz, Zeev. "The Effects of Strategic and Economic Interdependence on International Conflict Across Levels of Analyses." American Journal of Political Science, 53(1), 2009, 223240

[17] Mastanduno, Michael. "Economics and Security in Statescraft and Scholarship." International Organization, 52(4), 1998, 825-854

[18] Morrow, James, Randolph Siverson, and TressaTabares. "The Politics of Determinants of International Trade: The Major Powers." American Political Science Review, 92 (3), 1998, 649-661 
[19] Morrow, James. "How Could Trade Affect Conflict?.” Journal of Peace Research, 36(4), 1999, 481-489

[20] Oetzel, Jennifer, and Kathleen Getz. "Why and how might firms respond strategically to violent conflict?." Journal of International Business Studies, 43(2), 2012, 166-186

[21] Polachek, Solomon. "Conflict and Trade." Journal of Conflict Resolution, 24(1), 1980, 5578

[22] Polachek, Solomon W. \& Seiglie, Carlos. "Trade, Peace and Democracy: An Analysis of Dyadic Dispute," Handbook of Defense Economics, Elsevier, 2007.
[23] Pollins, Brian M. "Conflict, Cooperation, and Commerce: The Effect of International Political Interactions on Bilateral Flows." American Journal of Political Science, 33, 1989, 737-761

[24] Simmons, Beth. "Rules over Real Estate: Trade, Territorial Conflict, and International Borders as Institution." Journal of Conflict Resolution, 49(6), 2005, 823-848

[25] Yujuico, Emanuel. "The Real Story behind the South China Sea Dispute." Journal of International Affair, Diplomacy, and Strategy LSE, 2010. 